\title{
AKTIVITAS PEMASARAN PRODUK TABUNGAN PADA PT. BANK PEMBANGUNAN DAERAH (BPD) SUMATERA BARAT CABANG UTAMA PADANG
}

\author{
Ferdy, Afriyeni \\ Akademi Keuangan dan Perbankan Padang \\ Afriyeni.yen@gmail.com
}

\begin{abstract}
The economy of a nation requires a regulatory pattern, as well as economic management in an integrated and directed to the level of welfare of many communities. Economic institutions are an institution that has activities in the field of economy for the fulfillment of community needs and cooperate in the management and move all economic potentials to be useful optimally. The purpose of this study is to find out how the activity of marketing savings products at PT. Bank Pembangunan Daerah Sumatera Barat Cabang Utama Padang. Marketing activity is the main activity undertaken by the company either a goods or service company in an effort to maintain the continuity of its business. PT. Bank Pembangunan Daerah Sumatera Barat Cabang Utama Padang sells Produk Tabungan that have advantages eg Produk Tabungan Sikoci, is a type of Tabungan that is intended for individual customers and foundations which in this product provides a chance to win prizes for savers are drawn twice a year and also provide insurance to customers, Types of Tabungan are Tabungan Sikoci, Tabungan Simpeda, Tabungan Simpel and TabunganKu. In this case can be seen the development of the number of customers PT. Bank Pembangunan Daerah Sumatera Barat Cabang Utama Padang has an increase every year in the period 2013-2017 This proves that the marketing performance of PT. Bank Pembangunan Daerah Sumatera Barat Cabang Utama Padang can be said good, because the results obtained are greater than the costs incurred in marketing Produk Tabungan.
\end{abstract}

Keywords : Marketing Activity, Saving Product, Marketing Product.

\section{PENDAHULUAN}

Perekonomian suatu bangsa memerlukan pola pengaturan, serta pengelolaan ekonomi secara terpadu serta terarahnya bagi tingkat kesejahteraan masyarakat banyak. Lembaga perekonomian merupakan suatu lembaga yang memiliki kegiatan dibidang ekonomi demi terpenuhinya kebutuhan masyarakat serta bekerjasama dalam pengelolaan dan menggerakkan semua potensi ekonomi agar dapat berguna secara optimal.Menurut Ogi, (2014) bertambah banyaknya bank yang hadir diIndonesia dengan berbagai bentuk macam promosi yang dilakukan guna menarik masyarakat untuk menggunakan produk bank tersebut dan juga meningkatkan jumlah nasabah. Semakin ketatnya persaingan dalam bisnis perbankan mendorong para pelaku bisnis perbankan untuk mampu memberikan inovasi penawaran atas produk dan jasa dalam 
melakukan pemasaran. Setiap bank memiliki berbagai jenis produk yang akan ditawarkan berdasarkan keinginan dan kebutuhan masyarakat. Dalam melakukan penawaran produk pada suatu bank akan terjadi sutau persaingan antara bank satu dengan bank yang lainnya sehingga perlu ditingkatkan aktivitas pemasaran pada setiap bank. Hal ini dilakukan agar masyarakat lebih tahu dan berminat dalam mengambil manfaat dari produk-produk yang ditawarkan sesuai dengan kebutuhan, disamping itu aktivitas pemasaran yang harus ditijnau dan dikembangkan sesuai dengan perkembangan pasar. Menurut Undang-Undang Nomor 10 Tahun (1998) Tentang Perubahan undang-undang No.7 Tahun 1992 Tentang Perbankan, Ada 2 jenis bank yaitu bank umum, dan bank perkreditan rakyat. Bank umum merupakan suatu bank yang kegiatan usahanya dilakukan dengan cara konvesional dan didasarkan prinsip syariah yang kegiatannya memberikan jasa lalu lintas pembayaran. Sedangkan bank perkreditan rakyat (BPR) adalah bank yang melaksanakan kegiatan usahanya secara konvesional atau berdasarkan prinsip syariah yang dalam kegiatan usahanya tidak memeberikan jasa lalu lintas pembayaran. Dalam hal ini PT. BPD Sumbar Cabang Utama Padang termasuk ke dalam Bank Umum yang mana kegiatan usaha yang dilakukan secara konvesional dan berdasarkan prinsip syariah.

Salah satu bank yang ada di Sumatera Barat khususnya Kota Padang yaitu PT. Bank Pembangunan Daerah (BPD) Sumbar Cabang Utama Padanguntuk lebih menarik minat nasabahnya untuk mau menyimpan uangnya dibank tersebut, maka pihak bank melakukan pemasaran produk tabungannya dengan cara meningkatkan pelayanan terhadap nasabah dan memberikan hadiah undian sekali dalam setahun berupa bingkisan kepada nasabah yang memiliki jumlah tabungan yang banyak. Menurut Fandi, (2008) pemasaran jasa bank merupakan suatu usaha, suatu proses setiap tindakan atau kegiatan yang dibutuhkan dan diinginkan melalui penciptaan yang dapat ditawarkan oleh suatu pihak kepada pihak lain. keberhasilan suatu perusahaan dalam mencapai tujuannya dalam berbisnis tergantung pada kemampuan bank menjalankan fungsi suatu pemasaran jasa sebagai sesuatu yang penting karena merupakan fungsi suatu bisnis atau usaha yang berinteraksi langsung dengan orang banyak. Menurut Ajeng, (2016) aktivitas pemasaran merupakan suatu cara bank mencapai sebuah tujuan, sehingga menjalankan sebuah usaha diperlukan adanya pengembangan aktivitas pemasarannya. Aktivitas pemasaran tabungan yang dilakukan untuk meningkatkan dana yang dapat terkumpul dari nasabah yang dikenal dengan tabungan. Dari aktivitas pemasaran yang dilakukan oleh PT. BPD Sumatera Barat Cabang Utama adalah melaui tabungan.Tabungan merupakan sebagian dari pendapatan yang tidak dikonsumsi atau sisa dari yang dikonsumsi, Jadi disimpan dan dipergunakan dimasa yang akan datang atau dicairkan saat dibutuhkandan itu bisa dilihat dari perkembangan jumlah nasabah PT. BPD Sumatera Barat Cabang Utama Padang yang mengalami tingkatan pada tahun 2013 sampai dengan tahun 2017. Adapun perkembangan jumlah nasabah tabungan PT. BPD Sumatera Barat Cabang Utama Padang dapat dilihat pada tabel dibawah ini : 


\section{Tabel 1}

Perkembangan Jumlah Nasabah dan Saldo Nominal PT. BPD Sumatera Barat Cabang Utama Padang Tahun 2013 s/d 2017

\begin{tabular}{|c|c|c|}
\hline Tahun & $\begin{array}{c}\text { Jumlah Nasabah } \\
\text { (Orang) }\end{array}$ & $\begin{array}{c}\text { Saldo Nominal } \\
\text { (Rp.000) }\end{array}$ \\
\hline 2013 & 1.146 .948 & 3.586 .083 \\
\hline 2014 & 1.010 .378 & 3.774 .086 \\
\hline 2015 & 1.020 .743 & 4.315 .950 \\
\hline 2016 & 1.057 .852 & 4.692 .341 \\
\hline 2017 & 1.114 .687 & 5.221 .625 \\
\hline
\end{tabular}

Sumber : PT. BPD Sumatera Barat Cabang Utama Padang, 2018

Dari tebel 1.1 diatas dapat dilihat perkembangan jumlah tabungan pada tahun 2013 jumlah tabungan yang dimiliki adalah sebanyak 1.146 .948 orang dengan nominal Rp. 3.586.083.000 pada tahun 2014 mengalami penurunan dari 1.146.948 orang menjadi 1.010 .378 orang, akan tetapi mengalami kenaikan pada nominalnya sebesar Rp. 3.774.086.000, pada tahun 2015, 2016 dan 2017 mengalami peningkatan jumlah tabungan, dan juga nominalnya. Dapat dilihat bahwa jumlah nasabah dan saldo nominal PT. BPD Sumbar terus mengalami peningkatan dari tahun ketahunnya kecuali, lain halnya pada tahun 2014 jumlah nasabah mengalami penurunan.Meskipun demikian saldo nominal masih tetap terus naik dari tahun sebelumnya. Jumlah nasabah PT. Bank Pembangunan Daerah (BPD) Sumatera Barat Cabang Utama Padang turun pada tahun 2014, dikarenakan adanya perpindahan produk Tabungan Tabanas ke produk Tabungan Simpeda sehingga jumlah nasabah yang mempunyai rekening Tabungan Tabanas pindah ke Tabungan Simpeda. Penurunan jumlah nasabah pada tahun 2014 tidak merupakan masalah bagi PT. Bank Pembangunan Daerah (BPD) Sumatera Barat Cabang Utama Padang.maka PT. BPD Sumbar Cabang Utama Padang melakukan aktivitas pemasaran produk tabungan menggunakan kebijakan promosi seperti : Iklan (Advertising), Promosi penjualan (Sales Promotion), Penjualan Personal (Personal Selling), Publisitas (publicity).Bentuk-bentuk promosi yang dilakukan berupa pemberian kupon, kartu gambar, memberikan permainan, pemberian voucher, pemberian diskon, pemberian hadiah, dan kompetisi.

Perumusan Masalah

Rumusan masalah dalam penelitian ini adalah bagaimana aktivitas pemasaran produk tabungan pada PT. Bank Pembangunan Daerah (BPD) Sumatera Barat.

Tujuan Penelitian dan Manfaat Penelitian

Tujuan Penelitian

Adapun tujuan dari penulisan ini adalah untuk mengetahui bagaimana aktivitas pemasaran produk tabungan pada PT. Bank Pembangunan Daerah (BPD) Sumatera Barat. 
Manfat Penelitian

1) Bagi penulis merupakan alat untuk mengembangkan ilmu pengetahuan yang penuilis dapatkan selama berada dibangku kuliah dan memperluas pengetahuan.

2) Bagi perusahaan diharapkan bisa dijadikan bahan pertimbangan dalam menetapkan kebijaksanaan dalam aktivitas pemasaran produk tabungan.

3) Bagi pihak lain dapat dijadikan referensi penelitian berikutnya yang berkaitan dengan aktivitas pemasaran produk tabungan.

\section{METODE PENELITIAN}

Untuk keperluan penelitian ini, pengumpulan data dapat dilakukan dengan dua cara yaitu :

a. Riset Perpustakaan ( Library research)

Yaitu pengumpulan data dengan cara mempelajari teori-teori dari literature, laporan-laporan yang ada kaitannya dengan objek penelitian.

b. Riset Lapangan (Field research)

Yaitu melakukan penelitian langsung untuk mendapatkan data primer dan sekunder.

\section{Metode Analisa Data}

Dalam menganalisa data, penulis menggunakan metode analisa data kualitatif sebagai metode penelitian yang menjelaskan secara deskriptif menegenai aktivitas pemasaran produk tabungan pada PT. Bank Pembangunan Daerah (BPD) Sumatera Barat.

\section{HASIL DAN PEMBAHASAN Landasan Teori \\ Bank}

Bank merupakan lembaga keuangan umumnya didirikan dengan kewenangan untuk menerima simpanan uang, meminjamkan uang, dan menerbitkan promes atau yang dikenal sebagai bank note. Sedangkan menurut Undang-Undang Nomor 10 Tahun 1998 Tentang Perbankan, yang dimaksud dengan bank adalah badan usaha yang menghimpun dana dari masyarakat dalam bentuk simpanan dan menyalurkannya kepada masyarakat dalam bentk kredit dan bentuk-bentuk lainnya dalam meningkatkan taraf hidup rakyat banyak. Menurut (Novia, 2013) Bank adalah lembaga keuangan yang kegiatan utamanya adalah menghimpun dana dari masyarakat dan menyalurkannya kembali dana tersebut ke masyarakat serta memberikan jasa lainnya.

\section{Jenis-Jenis Bank}

Menurut Suliyanto, (2014) Berdasarkan jenisnya bank terdiri dari dua jenis yaitu bank umum dan Bank Perkreditan Rakyat (BPR). Bank umum adalah bank yang melaksanakan kegiatan usaha secara konvensional dan atau berdasarkan prinsip syariah yang dalam kegiatannya memberikan jasa dalam lalu lintas pembayaran, sedangkan BPR adalah bank yang melaksanakan kegiatan usaha secara konvensional dan atau berdasarkan prinsip syariah yang dalam kegiatannya tidak memberikan jasa dalam lalu lintas pembayaran.Bentuk hukum bank umum dan BPR dapat berupa Perseroan Terbatas (PT).bank umum terdiri dari bank 
umum pemerintah, bank umum swasta nasional devisa, bank swasta nasional non devisa, dan bank asing dan campuran. Dilihat dari Segi Kepemilikan Jenis bank selanjutnya dapat dilihat dari segi kepemilikan.Jenis Bank dilihat dari segi kepemilikan maksudnya adalah siapa saja yang memiliki Bank tersebut.Kepemilikan ini dapat dilihat dari akte pendirian dan penguasaan saham yang dimiliki Bank yang bersangkutan.(Ronny, 2013)

Jenis Bank dilihat dari segi kepemilikan adalah sebagai berikut:

Bank milik Pemerintah Dimana baik akte pendirian maupun modalnya dimiliki oleh pemerintah, sehingga seluruh keuntungan Bank ini dimiliki oleh pemerintah pula. Contoh: Bank Negara Indonesia 46 (BNI), Bank Rakyat Indonesia (BRI), Bank Tabungan Negara (BTN), dan Bank Mandiri.

Bank milik swasta nasional Merupakan Bank yang seluruhnya atau sebagian besarnya dimiliki oleh swasta nasional serta akte pendiriannya pun didirikan oleh swasta, begitu pula pembagian keuntungan diambil oleh swasta pula. Contoh Bank milik swasta nasional antara lain: Bank Bumi Putra, Bank Bukopin, Bank Central Asia, Bank Danamon, Bank Lippo, dan Bank swasta lainnya.

Dilihat dari segi status Pembagian jenis bank dari segi status merupakan pembagian berdasarkan kedudukan atau status Bank tersebut. Dalam praktiknya jenis Bank dilihat dari status dibagi kedalam dua macam yaitu :

Bank devisa

Bank yang berstatus devisa atau Bank devisa merupakan Bank yang dapat melaksanakan transaksi keluar negeri atau yang berhubungan dengan mata uang asing secara keseluruhan.

Bank non devisa

Merupakan kebalikan daripada Bank devisa, dimana transaksi yang dilakukan masih dalam batas-batas suatu negara.

\section{Fungsi Bank}

Secara umum, fungsi utama bank adalah menghimpun dana dari masyarakat luas dan menyalurkan kepada masyarakat dalam bentuk pinjaman atau kredit untuk berbagai tujuan. Fungsi bank sebagai Agen Of Trust maksudnya adalah bahwa bank sebagai Financial Intermediary menjalankan fungsinya atas dasar kepercayaan yang diterima oleh bank dari masyarakat. Kepercayaan masyarakat yang diberikan berupa amanat agar bank mengelola dan mengamankan dana yang disimpan masyarakat di bank tersebut. Fungsi bank sebagi Agen Of Trust ini tertentu tidak terlepas dari prinsip saling menguntungkan bagi kedua belah pihak. Fungsi bank sebagai Agen Of Development maksudnya adalah guna mewujudkan pembangunan dan kesejahteraan dalam perekonomian, bank dianggap sebagai lembaga yang cukup berperan.(Monang, 2013)

\section{Peranan Bank}

Dalam menjalankan kegiatanya bank mempunyai peran penting dalam sistem keuangan, yaitu:

a) Pengalihan Asset (asset transmutation) yaitu pengalihan dana atau asset dari unit surplus ke unit devisit. Dimana sumber dana yang diberikan pada pihak peminjam berasal pemilik dana yaitu unit surplus yang jangka waktunya dapat di atur sesuai dengan keinginan pemilik dana. Dalam hal ini bank berperan sebagai pengalih aset yang likuid dari unit surplus kepada unit defisit. 
b) Transaksi (transaction)Bank memberikan berbagai kemudahan kepada pelaku ekonomi untuk melakukan transaksi. Dalam ekonomi modern, transaksi barang dan jasa tidak pernah terlepas dari transaksi keuangan.Untuk itu produk-produk yang dikeluarkan oleh bank (giro, tabungan, deposito, saham dan sebagainya) merupakan pengganti uang dan dapat digunakan sebagai alat pembayaraan.

c) Likuiditas (liquidity)Unit surplus dapat menempatkan dana yang dimilikinya dalam bentuk produk-produk berupa giro, tabungan, deposito, dan sebagainya. Produk tersebut masing-masing mempunyai tingkat likuiditas yang berbedabeda. Untuk kepentingan likuiditas para pemilik dana dapat menempatkan dananya sesuai dengan kebutuhan dan kepentinganya. Dengan demikian bank memberikan fasilitas pengelolaan likuiditas kepada pihak yang mengalami surplus likuiditas dan menyalurkan kepada pihak yang mengalami kekurangan likuiditas.

d) Efisiensi (efficiency)Peran bank sebagai broker adalah menemukan peminjam dan pengguna modal tanpa mengubah produknya. Disini bank hanya mempelancar dan mempertemukan pihak-pihak yang saling membutuhkan.Adanya informasi yang tidak simetris antara peminjam dan investor meninbulkan masalah insentif.Peran bank menjadi penting untuk memecah masalah insentif tersebut.Untuk itu jelas peran bank dalam hal ini yaitu menjembatani dua pihak yang saling berkepentingan untuk menyamakan informasi yang tidak sempurna.

Jasa Layanan dan produk bank lainya

a) Kiriman uang (transfer)adalah jasa pengiriman uang lewat bank. pengiriman uang dapat dilakukan pada bank yang sama atau pada bank yang berlainan.

b) Kliring (clearing)adalah penagihan warkat (surat berharga seprti cek dan bilyet giro) yang berasal dari dalam kota. Proses penagihan biasanya hanya membutuhkan waktu 1 (satu) hari saja.

c) Inkaso (collection)adalah penagihan warkat (surat-surat berharga seperti cek, bilyet giro) yang berasal dari luar kota atau luar negeri. Proses penagihan inkaso biasanya membutuhkan waktu 1 (satu) minggu sampai 1 (satu) bulan, tergantung jarak lokasi penagihan.

d) Safe Deposit Boxadalah pelayanan jasa bank yang memberikan pelayanan penyewaan box (tempat) menyimpan barang-barang atau surat berharga milik nasabah suatu bank.

e) Bank Card atau lebih populer dengan sebutan kartu kredit atau juga uang plasticadalah kartu yang dapat digunakan untuk mengambil uang tunai atau digunakan untuk membayar sejumlah barang yang dibeli biasanya pada supermarket.

f) Bank Notesadalah jasa penukaran valuta asing( nilai tukar rupiah dengan mata uang asing).

g) Bank Garansiadalah jaminan bank yang diberikan kepada nasabah guna membiayai suatu usaha.

h) Bank Draftadalah wesel yang dikeluarkan oleh bank kepada para nasabahnya. wesel ini dapat di perjual belikan oleh nasabah saat membutuhkan uang tunai. 
i) Letter of Credit ( $L / C$ )adalah surat kredit yang diberikan bank kepada impotir dan ekspotir yang digunakan untuk melakukan pembayaran atas transaksi ekspor dan impor yang mereka lakukan.

j) Cek Wisata (travelers cheque)adalah alat yang dapat digunakan untuk pembayaran di berbagai lokasi wisata perbelanjaan atau hiburan. Contohnya hotel dan supermarket.

\section{Tabungan}

Menurut Taufiq, (2013) kegiatan yang berupa menghimpun dana dari masyarakat yang berupa simpanan nasabah yang mana penarikannya dapat dilakukan setiap jam kas belum ditutup berdasarkan persyaratan tertentu. Dilihat dari pengertian tabungan bahwa penghimpunan dana yang dilakukan BPD Sumbar Cabang Utama Padang yaitu berbentuk simpanan dana masyarakat dengan syaratsyarat yang mudah dalam hal pembukaan rekening tabungan.

\section{Jenis-jenis Tabungan}

a. Tabungan Sikoci

Kesempatan besar meraih hadian tabungan yang diundi dua kali setahun bagi setiap penabung Sikoci PT. BPD Sumbar.

1) Keunggulan Tabungan Sikoci

a) Meningkatkan bonafiditas anda.

b) Pelayanan dilaksanakan secara cepat dan tepat.

c) Bunga menarik dan bersaing, dihitung berdasarkan saldo harian.

d) Otomatis dijamin asuransi jiwa.

e) Kesempatan memperoleh hadiah lebih besar, minimal saldo Rp.100.000,- atau sesuai ketentuan.

f) Pengembalian dan penyetoran serta pemindah bukuan dapat disemua Kantor Bank Nagari (System On-line) sesuai ketentuan berlaku.

g) Dapat dijadikan sarana pembayaran Rekening Listrik, Rekening Telepon, Rekening Air, Uang Kuliah, PBB dan Pajak Lainnya, Kiriman Uang dll.

h) Dapat ditarik pada semua ATM Bank Nagari atau melalui ATM bersama diseluruh Indonesia.

2) Syarat Mudah

a) Mengisi formulir aplikasi permohonan Pembukaan Rekening Tabungan SIKOCI.

b) Foto Copy KTP, SIM / Paspor (WNA).

c) Setoran awal dan saldo minimal Rp.25.000,- atau sesuai ketentuan.

d) Lain-lain sesuai ketentuan berlaku.

b. Tabungan Simpeda

Tabungan di Bank Nagari yang bekerja sama dengan Bank Pembangunan Daerah Seluruh Indonesia (BPDSI).

1) Keunggulan Tabungan Simpeda

a) Meningkatkan bonafiditas para penabung.

b) Pelayanan secara Cepat dan Tepat.

c) Bunga bersaing, dihitung berdasarkan saldo harian. 
d) Undian berhadiah, 2 (dua) kali setahun.

e) Kesempatan memperoleh hadiah cukup besar.

f) Dapat menarik dan menyetor serta pemindahbukuan disemua Kantor Bank Nagari (System On-line) sesuai ketentuan berlaku.

g) Dapat dijadikan sarana pembayaran Rekening Listrik, Rekening Telepon, Rekening Air, Uang Kuliah, PBB dan Pajak lainnya, Kiriman Uang dll.

h) Dapat ditarik pada ATM Bank Nagari dan ATM Bersama diseluruh Indonesia.

2) Syarat Mudah

a) Mengisi formulir aplikasi permohonan Pembukaan tabungan SIMPEDA.

b) Foto Copy KTP, SIM / Paspor (WNA).

c) Setoran awal dan saldo minimal Rp.10.000,- atau sesuai ketentuan.

\section{Pemasaran Jasa Bank}

d) Biaya administrasi sesuia ketentuan yang berlaku.

pemasaran jasa bank merupakan suatu usaha, suatu proses setiap tindakan atau kegiatan yang dibutuhkan dan diinginkan melalui penciptaan yang dapat ditawarkan oleh suatu pihak kepada pihak lain. Sedangkan pemasaran barang yaitu seluruh proses yang dimulai dari analisis pasar, mengantarkan produk ke pelanggan dan menerima umpan balik. Prosesnya bertujuan untuk mengetahui pasar yang tepat bagi produk dan penempatannya sedemikian rupa sehingga mendapat respon pelanggan yang baik.Ini mencakup promosi dan penjualan produk ke sasarannya, yaitu calon pembeli dan pelanggan tetap.keberhasilan suatu perusahaan dalam mencapai tujuannya dalam berbisnis tergantung pada kemampuan bank menjalankan fungsi suatu pemasaran jasa sebagai sesuatu yang penting karena merupakan fungsi suatu bisnis atau usaha yang berinteraksi langsung dengan orang banyak. Bank merupakan perusahaan jasa yang bertugas menghimpun dan menyalurkan dana dari dan ke masyarakat. Sebagaimana perusahaan jasa yang lain, bank juga harus mampu memberikan pelayanan yang baik, sehingga tercipta kepuasan pelanggan.Untuk menciptakan kepuasan pelanggan tersebut, bank harus mampu melakukan pengelolaan pemasaran yang professional.tujuan pemasaran bank secara umum adalah untuk:

a. Memaksimumkan konsumsi atau dengan kata lain memudahkan konsumsi sehingga dapat menarik nasabah untuk membeli produk yang ditawarkan bank.

b. Memaksimumkan kepuasan pelanggan melalui berbagai pelayanan yang diinginkan nasabah.

c. Memaksimumkan pilihan (ragam produk) dalam arti bank menyediakan berbagai jenis produk bank sehingga nasabah memiliki beragam pilihan pula.

d. Memaksimumkan mutu hidup dengan memberikan berbagai kemudahan kepada nasabah dan menciptakan iklim yang efisien.

\section{Aktivitas Pemasaran Produk Tabungan}

Aktivitas pemasaran merupakan kegiatan pokok yang dilakukan oleh perusahaan baik itu perusahaan barang atau jasa dalam upaya untuk 
mempertahankan kelangsungan usahanya.dikarenakan pemasaran merupakan salah satu kegiatan perusahaan, di mana secara langsung berhubungan dengan masyarakat, maka kegiatan pemasaran dapat diartikan sebagai kegiatan masyarakat yang berlangsung dalam kaitannya dengan pasar.

Aktivitas pemasaran yang dilakukan PT. BPD Sumbar Cabang Utama padang memasarkan produk Tabungan yang memiliki keunggulan misalkan pada Tabungan Sikoci, Tabungan Sikoci diperuntukkan bagi nasabah perorangan maupun yayasan yang mana dalam produk ini memberikan kesempatan meraih hadiah bagi penabung yang diundi dua kali dalam setahun dan juga memberikan asuransi kepada nasabah.

Teknik pemasaran yang dilakukan PT. BPD Sumbar Cabang Utama Padang melakukan berbagai bentuk promosi serta memperkenalkan produk kepada calon nasabah dengan cara yang kreatif guna menarik nasabah untuk menggunakan produk tersebut. PT. BPD Sumbar Cabang Utama Padang dalam memasarkan produk Tabungannya bekerja sama dengan sekolah-sekolah maupun perguruan tinggi, misalnya dengan menawarkan pembuatan kartu mahasiswa yang sekaligus berfungsi sebagai kartu tabungan (ATM), ini merupakan cara bank memasarkan sekaligus mempromosikan produk tabungan. Dalam hal ini yang bertanggung jawab dalam memasarkan produk tabungan ialah Marketing Funding.Marketing Fundingmerupakan petugas bank yang tidak hanya bertugas dalam menghimpun dana tabungan dari masyarakat tetapi juga memasarkan, mempromosikan serta menawarkan produk bank pada masyarakat.

Proses pemasaran yang dilakukan PT. BPD Sumbar Cabang Utama Padang, adanya produk yang ditawarkan kepada nasabah dengan harga yang terjangkau, membuat cabang kantor baru guna untuk memudahkan nasabah melakukan transaksi dan melakukan promosi di berbagai media cetak maupun media massa. Dalam hal ini guna menarik minat masyarakat serta masyarakat menentukan pilihannya untuk menggunakan produk tersebut.

Aktivitas pemasaran yang dilakukan PT. Bank Pembangunan Daerah (BPD) Sumatera Barat Cabang Utama Padang mengunakan konsep 7P yaitu :Produk(Product)PT. BPD Sumbar Cabang Utama Padang memanfaatkan produkproduk tabungan yang diunggulkan untuk menarik minat masyarakat menjadi nasabah. memahami kebutuhan beragam masyarakat, maka PT. BPD Sumbar Cabang Utama Padang memiliki produk tabungan yang bermanfaat bagi para nasabahnya seperti bunga bersaing, kartu kredit, Anjungan Tunai Mandiri (ATM). Harga (Price)Harga pada suatu bank disebut bunga, bunga pada produk tabungan yaitu bunga tabungan yang mana bunga tabungan merupakan biaya bagi bank dan merupakan pendapatan bagi nasabah. PT. BPD Sumbar Cabang Utama Padang memberikan harga yang terjangkau untuk memenuhi kebutuhan nasabahnya seperti pada produk tabungannya, Bagi nasabah baru diwajibkan melakukan setoran awal sebesar Rp 25.000 dan biaya administrasi sesuai dengan ketentuan yang berlaku serta bunga bersaing dihitung berdasarkan saldo harian sehingga memotivasi mereka untuk membuka tabungan di PT. Bank Pembangunan Daerah Sumbar Cabang Utama Padang.Promosi (Promotion)Promosi merupakan kegiatan yang dalam penerapannya menggunakan teknik dibawah pengendalian bank yang dapat memberikan informasi yang menarik tentang produk yang ditawarkan oleh 
PT. BPD Sumbar Cabang Utama Padang, baik secara langsung maupun melalui pihak yang dapat mempengaruhi pembelian. Dengan konsep promosi, PT. BPD Sumbar Cabang Utama Padang melakukan serangkaian promosi dari produkproduknya melalui berbagai media dan event seperti media iklan ditelevisi, koran, membuat spanduk.Lokasi tempat (Place)Pemilihan Tempat serta lokasi strategis menjadi salah satu keuntungan bagi bank karena mudah terjangkau oleh nasabah dalam pemilihan lokasi, PT. BPD Sumbar Cabang Utama Padang mempertimbangkan untuk membuka cabang baru kantornya pada wilayah yang cukup strategis sering terjadi transaksi usaha dari para nasabahnya sehingga mempermudah nasabahnyas dalam menjalankan transaksi keuangan meliputi lokasi yang membuat usaha atau kantor PT. BPD Sumbar Cabang Utama Padang akan menjadi andalan disuatu tempat lokasi yang strategis dan dapat dipastikan tidak akan sepi dari nasabah yang melakukan transaksinya.Orang (People)Merupakan aset utama dalam perusahaan jasa perbankan, dalam hal ini para karyawan PT. BPD Sumbar Cabang Utama Padang yang berada pada posisi depan (frontliner) yang langsung bertemu dan memberikan service kepada nasabahnya. karyawan yang memiliki kinerja tinggi akan menjadikan nasabah puas dan loyal. Faktor penting lainnnya yaitu sikap (attitude) dan motivasi (motivation) dari karyawan dalam perusahaan jasa. Karyawan yang diandalkan PT. BPD Sumbar Cabang Utama Padang yang dilengkapi dengan wawasan luas dan kemampuan tentang dunia perbankan yang tinggi akan membuat nasabah PT. BPD Sumbar Cabang Utama Padang dapat memberikan rasa percaya dan aman dalam melakukan transaksi di PT. BPD Sumbar Cabang Utama Padang.Proses (Process)Proses yang dilakukan PT. BPD Sumbar Cabang Utama Padang dengan membuka dan menutup kantornya dicabang dengan waktu yang telah ditentukan PT. BPD Cabang Utama Padang, karyawan juga diberikan kemampuan yang dapat mengikuti prosedur atau sistem yang merupakan standarnya seperti memberikan pelayanan service disertai dengan senyum untuk menyambut para nasabahnya. proses akan terus berlangsung sampai menjamin mutu layanan PT. BPD Sumbar Cabang Utama Padang, sehingga mendapat penilaian yang semakin baik.Bukti fisik (Physical Evidence)Bukti fisik yang dapat membuat PT. BPD Sumbar Cabang Utama Padang memiliki karakter dan nilai tambah dimata nasabahnya dengan memiliki cabang gedung kantor yang memberikan ciri khasnya seperti halnya bank dengan kantor gedung yang selalu memiliki tingkat yang tinggi, lalu didesain dengan interior, perlengkapan dan tata ruang rapi akan dapat member suasana hati baik kepada nasabahnya sehingga tidak akan enggan untuk selalu bertransaksi dicabang PT. BPD Sumbar Cabang Utama Tersebut. 
Tabel 2

Perkembangan Jumlah Nasabah, Saldo Nominal dan Biaya Promosi

PT. BPD Sumatera Barat Cabang Utama Padang Tahun 2013 - 2017

\begin{tabular}{|c|c|c|c|}
\hline Tahun & $\begin{array}{c}\text { Jumlah Nasabah } \\
\text { (Orang) }\end{array}$ & $\begin{array}{c}\text { Saldo Nominal } \\
\text { (Rp. 000) }\end{array}$ & $\begin{array}{c}\text { Biaya Promosi } \\
\text { (Rp. 000) }\end{array}$ \\
\hline 2013 & 1.146 .948 & 3.586 .083 & 16.892 \\
\hline 2014 & 1.010 .378 & 3.774 .086 & 14.178 \\
\hline 2015 & 1.020 .743 & 4.315 .950 & 15.588 \\
\hline 2016 & 1.057 .852 & 4.692 .341 & 15.345 \\
\hline 2017 & 1.114 .687 & 5.221 .625 & 12.163 \\
\hline
\end{tabular}

Sumber : PT. BPD Sumbar Cabang Padang, 2018

Dari tabel 3.1 diatas dapat disimpulkan bahwa jumlah nasabah mengalami peningkatan setiap tahunnya walaupun pada tahun 2014 mengalami penuruna tetapi jumlah nominal tabungan meningkat seriap tahunnya, begitu juga den0gan biaya promosi yang dikeluarkan berkurang setiap tahunnya.

Salah satu indikator yang terlihat pada tabel 3.1 yaitu biaya promosi, dapat dijelaskan bahwa kinerja pemasaran pada suatu bank dikatakan baik apabila hasil yang diperoleh lebih besar dibandingkan dengan biaya yang dikeluarkan. Dari uraian diatas dapat disimpulkan bahwa kinerja pemasaran yang dilakukan PT. BPD Sumbar Cabang Utama Padang dapat dikatakan sangat baik, karena hasil yang diperoleh lebih besar dibandingkan dengan biaya yang dikeluarkan dalam melakukan pemasaran dalam hal pemasaran produk tabungan.

\section{SIMPULAN}

Berdasarkan hasil penelitian, dapat disimpulkan sebagai berikut:

1. Aktivitas pemasaran produk tabungan yang dilakukan PT. BPD Sumbar Cabang Utama Padang menentukan keunggulan produk, teknik pemasaran, melakukan promosi, serta saluran distribusi dalam pemasaran produk tabungan yang bertanggung jawab dalam memasarkan produk ialah Marketing Funding juga menggunakan konsep 7P : Product, Price, Promotion, Place, People, Process, Physical Evidence.

2. Jenis produk yang diberikan PT. BPD Sumbar Cabang Utama Padang Tabungan Sikoci, Tabungan Simpeda, Simpel dan TabunganKu.

3. Perkembangan jumlah nominal tabungan dari tahun 2013 sampai tahun 2017 mengalami peningkatan setiap tahunya, dapat dilihat bahwa nominal tabungan lebih besar dibandingkan dengan biaya promosi yang dikeluarkan PT. BPD Sumbar Cabang Utama Padang.

4. Dalam memasarkan produk tabungan PT. BPD Sumbar Cabang Utama Padang bekerjasama dengan sekolah-sekolah maupun perguruan tinggi misalnya dengan menawarkan pembuatan kartu mahasiswa yang sekaligus berfungsi sebagai kartu tabungan (ATM), ini merupakan cara PT. BPD Sumbar Cabang Utama Padang dalam memasarkan sekaligus mempromosikan produk tabungan. 


\section{DAFTAR PUSTAKA}

Ajeng, E. (2016). Hasanah Di PT . Bank Negara Indonesia Syariah Kantor Cabang X. Jurnal Manajemen Dan Pemasaran Jasa, 9(1), 55-78.

Fandi, A. M. (2008). Analisis Strategi Pemasaran untuk Meningkatkan Penjualan Kendaraan Motor pada CV Turangga Mas Motor. Journal Ekonomi Manajemen, 1-14.

Hidayati, R. R., \& Marlius, D. (2018). Aktivitas Promosi Dalam Meningkatkan Dana Pihak Ketiga Pada PT. Bank Perkreditan Rakyat (BPR) Batang Kapas Pesisir Selatan. https://doi.org/10.31227/osf.io/8dgqn

Marlius, D. (2016). Pengaruh Bauran Pemasaran Jasa Terhadap Minat Nasabah Dalam Menabung Pada Bank Nagari Cabang Muaralabuh. https://doi.org/10.31227/osf.io/vdqgx

Monang, R. T. (2013). Analisis Faktor-Faktor Yang Mempengaruhi Keputusan Nasabah Menabung Di Bank Bca Kota Medan (Studi Kasus Etnis Cina). Jurnal Ekonomi Dan Keuangan, 1(3), 193-204.

Novia, P. H. (2013). Pengaruh Kinerja Keuangan Terhadap Pertumbuhan Laba Pada Perbankan Di BEI. Jurnal EMBA, 1(3), 711-721. Retrieved from http://portalgaruda.org

Ogi, S. (2014). Tinjauan Faktor-Faktor yang Mempengaruhi Keputusan Nasabah Dalam Memilih Tabungan Sikoci ( Studi Kasus: Bank Nagari Cabang Pembantu Padang Luar ). Polibisnis, 6(2), 55-68.

Ronny, K. (2013). Tinjauan Hukum Terhadap Pemberian Kredit Oleh Bank Perkeditan Rakyat (BPR) Berkaitan Dengan Jaminan. Jurnaal Ilmiah “Advokasi,"1(2), 57-67.

Safitri, R. N., \& Marlius, D. (2017). Penerapan E-Banking Dalam Meningkatkan Jasa Dan Layanan Perbankan Di PT. Bank Rakyat Indonesia Cabang Padang. https://doi.org/10.31227/osf.io/gkv8t

Suliyanto. (2014). Perbandingan Efisiensi Bank Perkreditan Rakyat Dan Bank Umum Dengan Pendekatan Data Envelopment Analysis. Jurnal Keuangan Dan Perbankan, 18(2), 297-306.

Susanti, F. (2015). Pengaruh Bauran Promosi Terhadap Keputusan Klien Dalam Memilih Radio Carano Sebagai Media Promosi Iklan. https://doi.org/10.31227/osf.io/b9ws7

Taufiq. (2013). Pengaruh Dana Pihak Ketiga Terhadap Kredit Pada Bank Perkreditan Rakyat Di Indonesia. Jurnal Ekonomi, Manajemen Akuntansi, 
(35), 1-15.

Undang-Undang Nomor 10 Tahun 1998 Tentang Perbankan. (n.d.), (Direktur Direktorat Hukum Bank Indonesia), 65. https://doi.org/10.1007/s13398-0140173-7.2.

Widayati, R. (2019). Aktivitas Pemasaran Produk Simpanan PT. Bank Tabungan Negara (Persero)Tbk Kantor Cabang Padang. https://doi.org/10.17605/OSF.IO/3Z5YC

Widayati, R. (2019). Aktivitas Pemasaran Produk Tabungan Pada PT. Bpr Rangkiang Denai Payakumbuh Barat. https://doi.org/10.17605/OSF.IO/S3UZM 